\title{
Discovery and validation of novel protein biomarkers in ovarian cancer patient urine
}

Jarrod J Sandow ${ }^{1 \#,}$, Adam Rainczuk2,3\#, Giuseppe Infusini1 ${ }^{1}$, Ming Makanji2,3, Maree Bilandzic ${ }^{2,3}$, Amy L Wilson',3, Nicole Fairweather,4 Peter G Stanton², Daniel Garama ${ }^{2,3}$, Daniel Gough ${ }^{2,3}$, Thomas WJoblings, Andrew I Webb ${ }^{1 *}$, Andrew N Stephens ${ }^{2,3,4 *}$

1 The Walter \& Eliza Hall Institute, 1G Royal Parade, Parkville, VIC, Australia; Department of Medical Biology, The University of Melbourne, Parkville, VIC, Australia

2 Department of Molecular and Translational Sciences, Monash University, VIC, Australia

${ }^{3}$ Centre for Cancer Research, Hudson Institute of Medical Research, VIC, Australia

${ }^{4}$ Epworth Research Institute, Epworth HealthCare, Richmond, VIC, Australia

5 Obstetrics and Gynaecology, Monash Medical Centre, Clayton VIC 3168 Australia

\# These authors contributed equally to the manuscript

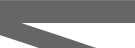

*Corresponding authors

Dr Andrew N. Stephens, Hudson Institute of Medical Research, 27-31 Wright St Clayton, VIC

3168 Australia Phone: +613 8572 2686. Fax: +6139594 7909.

E-mail Andrew.N.Stephens@hudson.org.au

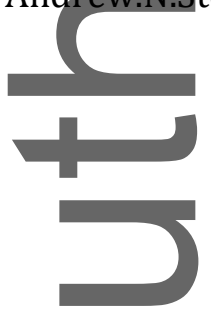

This is the and mascript accepted for publication and has undergone full peer review but has not been thr on th copyediting, typesetting, pagination and proofreading process, which may lead to differences betw this version and the Version of Record. Please cite this article as doi: 10.1002/prca.201700135.

This article is protected by copyright. All rights reserved. 


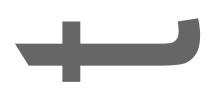

Dr Andrew I. Webb, The Walter \& Eliza Hall Institute, 1G Royal Pde, Parkville, VIC, Australia,

Phone: +613 9345 2832. Fax: +61393470852.

E-mailwebb@wehi.edu.au

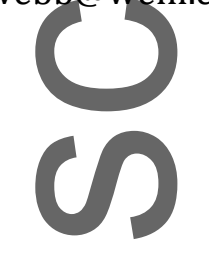

Keywords: biomarkers, urinary system, Ovarian cancer

Abbreviations: LFQ, label-free quantitation; PRM, Parallel Reaction Monitoring; FDR, false discovery rate; ROC, receiver operating characteristic

\section{ABSTRACT}

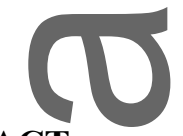

Purpose

For the vast majority of ovarian cancer patients, optimal surgical debulking remains a key prognostic factor associated with improved survival. A standardized, biomarker-based test, to pre-operatively discriminate benign from malignant disease and inform appropriate patient triage, is highly desirable. However, no fit-for-purpose biomarkers have yet been identified.

\section{ExperimentalDesign}

We conducted a pilot study consisting of 40 patient urine samples (20 from each group), using labelfree quantitative (LFQ) mass spectrometry, to identify potential biomarker candidates in urine from individual ovarian cancer patients. To validate these changes, we used Parallel Reaction Monitoring (PRM) to investigate their abundance in an independent validation cohort $(n=20)$ of patient urine samples.

This article is protected by copyright. All rights reserved. 
$\underline{\text { Results }}$

LFQ analyses identified 4394 proteins (17,027 peptides) in a discovery set of 20 urine samples. 23 proteins were significantly elevated in the malignant patient group compared to patients with benign disease. Several proteins, including LYPD1, LYVE1, PTMA and SCGB1A1 were confirmed to be enriched in the urine of ovarian cancer patients using PRM. We also identified the established ovarian cancer biomarkers WFDC2 (HE4) and Mesothelin (MSLN), validating our approach.

Conclusions and Clinical Relevance

This is the first application of a LFQ-PRM workflow to identify and validate ovarian cancer-specific biomarkers in patient urine samples.

INTRODUCTION

High grade serous ovarian cancers are typically diagnosed at an advanced stage, and account for around $90 \%$ of all ovarian cancer related deaths ${ }^{[1]}$. For the vast majority of these patients, optimal surgical debutking is strong prognosticator positively associated with survival ${ }^{[2]}$; thus, the identification of malignancy, and rapid referral for specialist treatment, is crucial to maximize the impact of primary therapies. The most widely used triage system is the Risk of Malignancy Index (RMI), incorporating CA125 measurement, menopausal status and ultrasound imaging to predict malignancy ${ }^{[\beta]}$. However, a lack of availability and poor imaging standardization can significantly impact RMI implementation and scoring ${ }^{[4]}$. The combined measurement of CA125 and HE4 in serum, the only FDA-approved biomarkers for ovarian cancer, can also be used (with menopausal status) to calculate the Risk of Malignancy Algorithm (ROMA) and stratify patients into high- and low-risk groups ${ }^{[5]}$. CA125 and HE4 together can also provide improved accuracy for monitoring tumor progression or recurrence. However, neither marker alone is appropriate for diagnosis; and HE4 remains an expensive test, with limited availability ${ }^{[6]}$. Accordingly, there remains an unmet clinical

This article is protected by copyright. All rights reserved. 
need for new biomarkers that achieve rapid, inexpensive and minimally invasive testing to monitor high-risk populations, detect tumor recurrence, and pre-operatively discriminate between benign and malignant ovarian disease ${ }^{[7]}$.

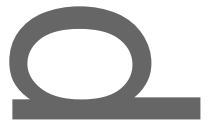

Numerous studies have sought to identify disease biomarkers in urine, with a view to the development of clinically relevant diagnostic tests ${ }^{[8,9]}$. As a sample type, urine offers simplified, non-invasive sample collection and storage relative to blood samples ${ }^{[10]}$; moreover, urine proteins are stable over time, increasing the consistency of data in both discovery experiments and the routine measurement of analytes ${ }^{[11]}$. The urine proteome lacks very high abundant proteins to that of plasma, which typically hamper proteomic analysis ${ }^{[12]}$, thus avoiding the need for extensive protein depletion ${ }^{[13]}$. Several FDA-approved urine protein biomarkers are now in clinical use for monitoring bladder cancer and the early detection of acute kidney injury ${ }^{[14]}$, supporting the use of urine-derived proteins as biomarkers of disease. In recent years, both human epididymis protein 4 (HE4/WFDC2) and mesothelin (MSLN) have been extensively investigated for their diagnostic potential as urine-based disease markers for ovarian cancer ${ }^{[15,16]}$ and can correctly discriminate malignancy at similar efficacy to serum-based testing of HE4 and MSLN ${ }^{[8]}$.

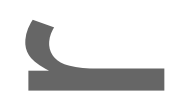

Label-free quantitative mass spectrometry (LFQ), whilst well-established as a proteomic discovery tool, has seen only limited application in the analysis of ovarian cancer-related proteomic changes to date [17]. Only a single study has applied LFQ to examine the urine peptidome of ovarian cancer patients versus healthy controls [18]. In previous work, we used isotope-coded protein labeling (ICPL) and MALDI MS/MS to identify urinary biomarkers of ovarian cancer [19], Whilst several potential disease biomarkers - both established and novel -

This article is protected by copyright. All rights reserved. 
were identified, both the dynamic range of the ICPL-MALDI approach and our ability to accurately quantitate changes was limited [19].

Here we report a pilot study applying LFQ, followed by targeted parallel reaction monitoring (PRM) to discover and validate ovarian cancer-related protein changes in urine samples from multiple individual patients. Discovery experiments using LFQ were conducted in a cohort of patients $(n=20$; cohort 1), and were followed by PRM validation using an independent patient cohort ( $\mathrm{n}=20$; cohort 2 ). The workflow identified a number of novel proteins that were significantly upregulated in the validation disease cohort. This is the first use of LFQ-PRM for ovarian cancer biomarker discovery, and establishes the methodology required for subsequent studies to evaluate specific disease biomarkers of ovarian cancer.

\section{Materials \& Methods}

\section{Clinical samples}

Urine was accessed from bio-banked samples, collected prospectively from women undergoing surgery for suspected gynaecological malignancies during the period 2008 - 2015. Information regarding collection and purification of urine proteins is located in supplementary information. Ethical approval for this study was obtained from the Southern Health Human Research Ethics Committee (HREC certificate \#06032C), and all participants providing prior informed written consent. Sample details are summarized in Table 1.

\section{Label Free Quantitation Mass Spectrometry and data analysis}

Urine protein samples were processed in $20 \mu \mathrm{g}$ aliquots resuspended in $6 \mathrm{M}$ Urea, $100 \mathrm{mM}$ DTT and $100 \mathrm{mM}$ Tris- $\mathrm{HCF}(\mathrm{pH}$ 7.0) and digested with trypsin using the Filter Aided Sample Preparation (FASP) column protocol as described previously ${ }^{[20]}$ (Expedeon Inc., CA, USA). Peptide This article is protected by copyright. All rights reserved. 
concentrations were measured using a NanoDrop 2000 (Thermo-Fisher) at $205 \mathrm{~nm}$, and acidified with trifluoroacetic acid (TFA; final 0.1\%). Solvent was removed in a CentriVap concentrator (Labconco) and peptides were resuspended in MilliQ water containing 3\% acetonitrile (ACN) and $0.1 \%$ formic acid (FA) at a final concentration of $100 \mathrm{ng} / \mu \mathrm{l}$. A $5 \mu 1$ aliquot of each sample was analyzed by nanoflow liquid chromatography tandem-mass spectrometry (LC-MS/MS) on a nanoAcquity system (Waters, Milford, MA, USA) coupled to a Q-Exactive mass spectrometer (Thermo Fisher Scientific, Bremen, Germany) through a nanoelectrospray ion source (Thermo Fisher Scientific). Peptides were loaded on a $20 \mathrm{~mm}$ X $180 \mu \mathrm{m}$ trap column (2G-V/MTrap $5 \mu \mathrm{m}$ Symmetry C18) at $1 \%$ buffer B, and separated by reverse-phase chromatography using a $250 \mathrm{~mm}$ X $75 \mu \mathrm{m}$ column $(1.7 \mu \mathrm{m}$ BEH130 C18) on a 120 minute linear gradient from $1 \%$ to $35 \%$ buffer B (A: Milli-Q water, 3\% ACN, 0.1\% FA; B: $99.9 \% \mathrm{ACN}, 0.1 \% \mathrm{FA})$ at $500 \mathrm{nl} / \mathrm{min}$ constant flow rate. The Q-Exactive was operated in a datadependent acquisition (DDA) mode, switching automatically between one full-scan and subsequent MS/MS scans of the ten most abundant peaks. The instrument was controlled using Exactive series version 2.1 and Xcalibur 3.0. Full-scans $(\mathrm{m} / \mathrm{z} 350-1,850)$ were acquired with a resolution of 70,000 at $200 \mathrm{~m} / \mathrm{z}$. The 10 most intense ions were sequentially isolated with a target value of 10000 ions and an isolation width of $3 \mathrm{~m} / \mathrm{z}$ and fragmented using $\mathrm{HCD}$ with normalized collision energy of 27 and stepped collision energy of $15 \%$. Maximum ion accumulation times were set to $50 \mathrm{~ms}$ for full MS scan and $150 \mathrm{~ms}$ for MS/MS. Underfill ratio was set to $2 \%$ and dynamic exclusion was set to $60 \mathrm{sec}$.

Raw files were analyzed using MaxQuant ${ }^{[21]}$ (version 1.5.1.2), The database search was performed using the Ludwig NR non-redundant protein database (version Q114, http://www.wehi.edu.au/faculty/advanced_research_technologies/proteomics/wehi_systems_biology_ mascot_server/) with strict trypsin specificity allowing up to 2 missed cleavages. The minimum required peptide length was set to 7 amino acids.

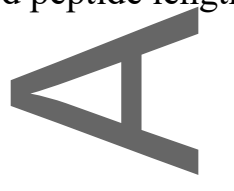

This article is protected by copyright. All rights reserved. 
Carbamidomethylation of cysteine was set as a fixed modification while $\mathrm{N}$-acetylation of proteins $\mathrm{N}$-termini, oxidation of methionine and pyroglutamate at peptides $\mathrm{N}$-termini Glu and Gln were set as variable modifications. During the main search, precursor ion mass error tolerance was set to $4.5 \mathrm{ppm}$ and fragment ions were allowed a mass deviation of $20 \mathrm{ppm}$. PSM and protein identifications were filtered using a target-decoy approach at a false discovery rate (FDR) of 1\%. The match between runs option was enabled with a match time window of 1 min and an alignment time window of $20 \mathrm{~min}$. Further analysis was performed using a custom pipeline developed in Pipeline Pilot (Biovia) and R (see supplementary information for a detailed description). The mass spectrometry proteomics data have been deposited to the ProteomeXchange Consortium via the PRIDE[22] partner repository with the dataset identifier PXD007962.

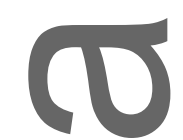

Parallel Reaction Monitoring Mass Spectrometry and data analysis

PRM analyses were preceded by DDA to define peptide retention times. PRM samples were analyzed by nanoflow LC-MS/MS on a nanoAcquity system (Waters) coupled to a Q-Exactive mass spectrometer (Thermo Fisher Scientific) through a nanoelectrospray ion source (Thermo Fisher Scientific). Peptide mixtures were directly injected on a $250 \mathrm{~mm}$ x $75 \mu \mathrm{m}$ analytical column packed into a silica emitter tip (in-house; $1.7 \mu \mathrm{m}$ BEH130 C18) at $1 \%$ buffer B, and separated by reverse-phase chromatography on a 90 minute linear gradient from $1 \%$ to $35 \%$ buffer Bat a 400nl/min constant flow rate. The PRM method combined two scan events starting with a full scan event followed by up to 30 targeted MS/MS scans for charge 2+ and 3+ precursor ions from a scheduled precursor inclusion list with a \pm 5 min retention time window. Full-scans $(\mathrm{m} / \mathrm{z} 350-1,850)$ were acquired with a resolution of 70,000 at $200 \mathrm{~m} / \mathrm{z}$. The PRM

This article is protected by copyright. All rights reserved. 
scans were run at a resolution of 17,500 at $\mathrm{m} / \mathrm{z} 200$. The targeted peptides were isolated using a $2.4 \mathrm{~m} / \mathrm{z}$ window. Fragmentation was performed with a normalized collision energy (NCE) of 27.

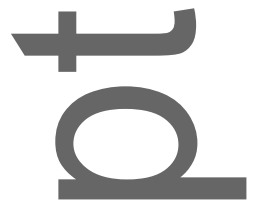

Skyline software ${ }^{[23]}$ was used for analysis of PRM data. The quantification was based on the sum of the area under the curves (AUC) of three to six fragments of the selected peptides and the ratio between peptide fragments of each patient sample. Full scan data was searched using MaxQuant and feature intensities for PRM scans were normalized by converting the features identified in the allPeptides table to base 2 logarithms and then multiplying each feature value by the ratio of maximum median intensity of all replicates over median replicate intensity. Receiver operating characteristics (ROC) analysis was performed using the R package pROC [24]. ROC analysis was performed for the ovarian cancer patients against benign patients using the Log2 summed intensity values for peptides analyzed using PRM for each selected protein.

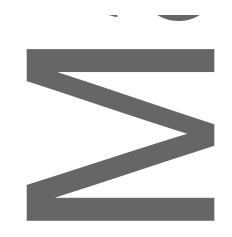

\section{RESULTS \\ Experimental strategy and rationale}

Urine proteomies has shown promise as a source of clinically relevant biomarkers of ovarian cancer ${ }^{[8]}$. In this study, we evaluated the application of label-free mass spectrometry and PRM to identify and validate new urinary biomarkers for the differentiation of benign from malignant ovarian disease. The overall strategy and simplified workflow is shown in Figure 1. In total, 40 urine samples ( $n=20$ malignant, $n=20$ benign) were collected from individual patients for this study (Table 1) and randomly assigned into either discovery or validation sets. To provide

This article is protected by copyright. All rights reserved. 
consistency at point-of-collection, urine samples were obtained intraoperatively from anaesthetized patients immediately prior to surgery, and processed identically. This standardization overcomes the variability introduced using typical collection methods (midstream, second morning void) reported in other proteomic studies [14]. Discovery experiments using LFQ were performed using one cohort ( $n=10$ per group; cohort 1 ) to identify and prioritize proteins that were altered in malignant versus benign ovarian disease. The intensity distributions between patient samples demonstrated low systematic variation (Fig.2). PRM validation experiments were then performed using the independent second cohort $(n=10$ per group; cohort 2), providing strong evidence for selected proteins that could potentially indicate the presence of ovarian malignancy.

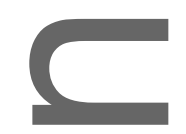

Identification of differentially expressed proteins by LFQ

Using the LFQ workflow we identified a total of 4394 proteins $(17,027$ peptides) in the discovery cohort samples, with 3750 proteins (15,666 peptides; CV 30.9\%) identified from malignant and 3950 proteins (14,326 peptides; CV 21.7\%) from benign groups (Fig.3A and 3B; Supplementary Table 1). Comparison of the identified species revealed an overlap of $75.2 \%$ amongst proteins (and 76.1\% of identified peptides) between the two groups (Fig.3C and D). A total of 444 unique proteins (1361 peptides) and 644 unique proteins (2701 peptides) were associated with the malignant or benign sample groups, respectively.

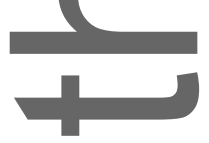

We utilized a LFQ analysis pipeline (see materials and methods) to perform a pair-wise differential expression analysis of the two patient groups. Using this approach, 23 proteins were found to be significantly enriched in late stage relative to benign samples (Fig.4 and Supplementary Table 2 and This article is protected by copyright. All rights reserved. 
3). The majority of proteins highlighted have established links with ovarian cancer (references shown in Supplementary Table 3), demonstrating the effectiveness of the label-free quantitation approach to identify ovarian cancer-specific proteins enriched in the urine of patients.

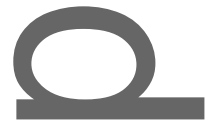

Ten proteins showing significant differences between malignant and benign groups in the discovery cohort were selected for further validation (Supplementary Table 4), based on their observed enrichment in cancer patient urine and potential relevance to ovarian cancer. To evaluate their tumor specificity, we assessed their abundance and localization in ovarian tumor tissues in silico using data from the Human Protein Atlas (Supplementary Table 3) ${ }^{[25]}$. Eight of the ten proteins were found to be expressed in ovarian tumor tissues, whilst two proteins (LYVE1 and SCGB1A1) were not stained; each of these, however, has previously been associated with ovarian cancers ${ }^{[26,27]}$.

\section{Validation of differentially expressed proteins using Parallel Reaction Monitoring}

The validation of protein abundance changes in urine using antibody-based approaches is challenging ${ }^{[19]}$. Indeed, we first attempted to validate several protein abundance changes using commercially available antibodies by western blotting, however, detection of target proteins at their expected sizes in urine samples was unsuccessful (Supplementary Figure 1). We therefore used targeted PRM to provide high sensitivity relative peptide quantification ${ }^{[28]}$. Validation was performed using individual patient samples from cohort 2, comprising 10 benign and 10 malignant patients. The selection of quantotypic peptides ${ }^{[29]}$ for PRM required that (i) peptides were unique to the protein of interest; (ii) were previously identified in greater than $50 \%$ of samples in a patient group; (iii) were between 7-35 amino acids in length; and (iv) were not semi-tryptic.

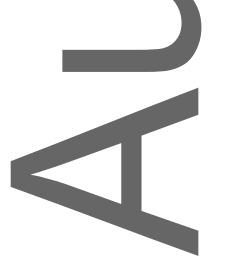

This article is protected by copyright. All rights reserved. 
Of the ten proteins identified as differentially expression in cohort 1 patients, significant differential expression of 7 of these candidate proteins was confirmed by PRM in the cohort 2 cancer patients for WFDC2, MSLN, LYPD1, SCGB1A1, IGFBP3, LYVE1 and PTMA (Fig.5, Table 2, Supplementary Fig.2). In the case of PTMA, only a single suitable peptide satisfied the criteria for quantotypic peptide inclusion (Table 2); nevertheless, this peptide was significantly elevated in cancer samples in agreement with the LFQ data. A comparison of the significantly differentially expressed proteins between the LFQ and PRM patient cohorts demonstrated good agreement between the two techniques (Table 3). Additionally, the degree of differential expression observed for these proteins was comparable to the established ovarian cancer urine biomarker, CA125 (Table 3, Supplementary Fig.3A). A ROC analysis was performed to assess the sensitivity and specificity of each protein in relation to ovarian cancer (Fig.6), with the results supporting the conclusions of the differential expression analysis. ROC analysis of the clinical CA-125 measurements demonstrated complete accuracy for classification of ovarian cancer patient within this cohort (Supplementary Fig.3B). These results demonstrate that we were able to quantify the reported ovarian cancer urine biomarkers, WFDC2 and MSLN ${ }^{[16]}$, in addition to identifying five novel biomarkers that are enriched in the urine of ovarian cancer patients. Our success indicates that measuring expression of these proteins in a larger patient cohort may produce clinically applicable biomarkers of advanced ovarian disease.
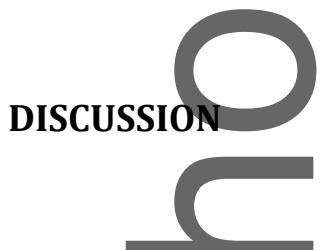

The urine proteome holds significant interest as a potential source of biomarkers, and is an easily accessible fluid for diagnostic and prognostic evaluation. However, low sensitivity of detection and difficulties associated with validation can prevent the full exploitation of this bodily fluid as a novel

This article is protected by copyright. All rights reserved. 
source of biomarkers ${ }^{[30]}$. Targeted mass-spectrometry methods, such as SRM and PRM, may help to increase detection sensitivity and also place less reliance on antibody validation ${ }^{[28,30,31]}$.

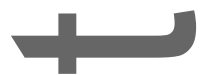

In this pilot study, we have focused on patients diagnosed with late-stage (FIGO Stage III), high grade serous ovarian cancers (HGSOCs), compared to those with benign ovarian masses. HGSOC patients represent the largest proportion of ovarian cancers diagnosed ${ }^{[1]}$, providing ample sample numbers for this pilot study and permitting discrete discovery and validation sets to be analyzed (4,394 nonredundant proteins / 17027 unique peptides in total; 1,388 non-redundant proteins / 9,190 unique peptides found in more than $50 \%$ of patient samples).

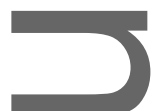

Amongst 23 proteins significantly increased in late stage ovarian cancer were the established ovarian cancer biomarkers WFDC2 (HE4) and mesothelin [16]. Each have well-documented roles in tumorigenesis, and their elevation is correlated with decreased survival rates and increased chemoresistance in epithelial ovarian cancer patients $[8,15,16,32]$. Both have also been identified as potential urinary biomarkers for ovarian cancer. Urinary WFDC2 detection by ELISA, when combined with CA125, has been used to identify patients at high risk for primary platinum therapy resistance [32]. Urinary mesothelin detection by ELISA, in combination with CA125 detection, can aid in diagnosis and monitoring of ovarian cancer patients [16]. Their identification in urine using PRM, and their observed abundance increase in malignancy consistent with extensive literature, provides confidence in the use of our LFQ-PRM approach to identify urinary biomarkers.

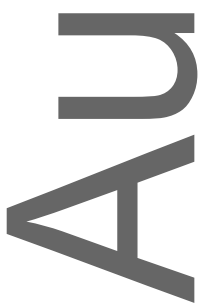

This article is protected by copyright. All rights reserved. 
Validation of protein abundance differences using antibody-based approaches is problematic [19]. Western blotting was unable to identify or validate protein changes, due to a lack of specificity and the detection of multiple reactive bands in urine samples. The most likely reason for this is the extensive proteolytic processing of proteins that occurs during prolonged incubation in the bladder, leading to the alteration and destruction of antigenic epitopes. Indeed, the majority of proteins in the urinary proteome are below $50 \mathrm{kDa}$ due to degradation by endogenous proteases, presenting difficulties in generating the correct antibody specificity [11,12,33]. By contrast, a targeted MS workflow as used here can detect multiple peptides and proteoforms, without reliance on antibodies [28,31]. An added advantage of this approach is that methods developed for successfully targeting peptides have the potential to be refined for use in a clinical setting, where selected reaction monitoring (SRM) is already in use [34].

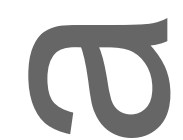

Amongst the proteins enriched in ovarian cancer patient urine, we validated five proteins that may serve as novel urinary biomarkers. Uteroglobin (SCGB1A1) is multifunctional, hormonally regulated globular protein associated with a variety of cancers [27,35,36]. Displaying involvement in both hormonal response and immunity, its functions remain largely unknown [35]. In recent studies, expression analysis and immunohistochemical staining of ovarian tumor tissues identified no significant difference in uteroglobin levels between ovarian cancer tissue and normal ovarian tissue [27]. Our study and a previous analysis [18] identified the increased abundance of endogenous uteroglobin peptides in ovarian cancer patient urine samples, strongly supporting its potential as a urinary biomarker candidate for further investigation. Insulin-like growth factor-binding protein 3 (IGFBP3) is expressed in a wide variety of cancer types (including lung, liver and breast), and methylation of the IGFBP3 gene has been identified as a prognostic marker of ovarian cancer progression [37]. LYPD1 (also known as putative HeLa

This article is protected by copyright. All rights reserved. 
tumor suppressor (PHTS)) is a membrane bound member of the lymphocyte antigen-6 (Ly6)/urokinase-type plasminogen activator receptor (Ly-6/uPAR) protein family [38]. Ly6/uPAR-proteins have diverse roles in cell migration, proliferation, immune cell maturation, macrophage actiyation and cytokine production [39]. In silico analysis of mRNA expression (from the Human Protein Atlas $[25,40]$ ) suggests that LYPD1 is abundantly expressed in the fallopian tube, the potential origin of most high grade serous epithelial ovarian tumours [1]. Lymphatic vessel endothelial hyaluronan receptor 1 (LYVE1) was previously investigated as part of a combined marker panel to evaluate lymphangiogenesis and prognosis in ovarian cancer [26]. Using immunohistochemical staining for LYVE1, Sundar et al. demonstrated positive reactivity in vascular endothelial cells in ovarian tumor tissues and identified lymphatic vessel density as a significant factor in progression-free survival of patients [26]. Prothymosin alpha (PTMA) is a nuclear oncoprotein commonly used as a prognostic marker in many tumour types [41]. In ovarian cancers, PTMA increases the CD8+ T-cell-mediated lysis of tumour cells, and inhibits tumour growth of orthotopic tumours in SCID mice ${ }^{[42] .}$

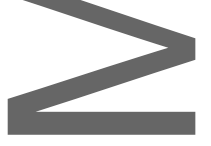

The accurate, pre-operative classification of ovarian adnexal masses can substantially improve the management of patients with suspected ovarian malignancy ${ }^{[43,44]}$; thus, biomarkers for rapid patient triage represent an important area of clinical need. Moreover, appropriate referral to a gynecologic oncology surgeon is clearly associated with improved outcomes for women with ovarian cancer ${ }^{[43,45]}$. Using the LFQ-PRM workflow developed in this study, we identified and validated multiple discriminating biomarkers in urine samples. The identification of established ovarian candidate markers (WFDC2 and mesothelin) in our dataset validates this approach. These findings warrant further investigation, particularly in the context of monitoring therapeutic response and disease This article is protected by copyright. All rights reserved. 
recurrence. Ongoing studies will focus on expanding patient numbers, and also evaluate those rare patients diagnosed with early-stage (FIGO stage I) disease.

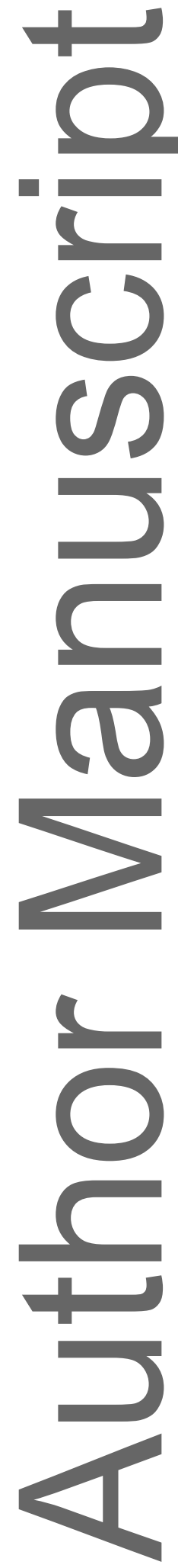

This article is protected by copyright. All rights reserved. 


\section{ACKNOWLEDGEMENTS}

The authors acknowledge Rhiannon Dudley for the collection of clinical samples. Funding support was provided by the Ovarian Cancer Research Foundation Inc., Australia (www.OCRF.com.au) and by the Victorian Government's Operational Infrastructure Support Program. Clinical samples were provided by the Ovarian Cancer Research Foundation Inc. sponsored Ovarian Cancer Tissue Biobank located at the Hudson Institute, Australia.

\section{CONFLICT OF INTEREST}

The authors declare no conflicts of interest.

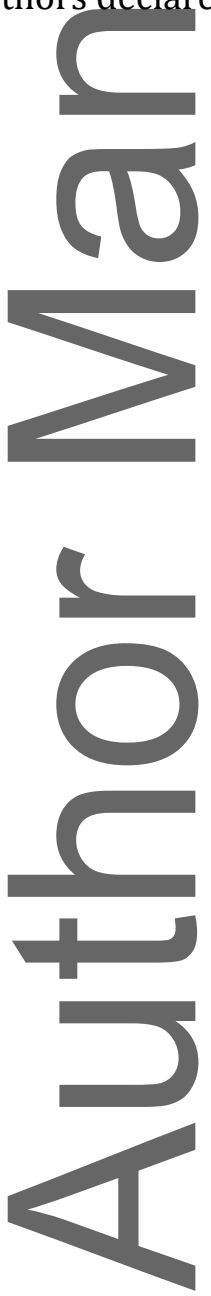

This article is protected by copyright. All rights reserved. 


\section{REFERENCES}

[1] R. J.Kurman, M. Shih Ie, Am J Pathol 2016, 186, 733.

[2] V. D. Sioulas, M. B. Schiavone, D. Kadouri, O. Zivanovic, K. L. Roche, R. O'Cearbhaill, N. R. Abu-Rustum, D. A. Levine, Y. Sonoda, G. J. Gardner, Gynecologic oncology 2017, 145, 15.

[3] I. Jacobs, D. Oram, J. Fairbanks, J. Turner, C. Frost, J. Grudzinskas, BJOG: An International Journal of Obstetrics \& Gynaecology 1990, 97, 922.

[4] R. G.Moore, M. Jabre-Raughley, A. K. Brown, K. M. Robison, M. C. Miller, W. J. Allard, R. J. Kurman, R.C. Bast, S. J. Skates, American journal of obstetrics and gynecology 2010, 203, 228. e1.

[5] R. G. Moore, D. S. McMeekin, A. K. Brown, P. DiSilvestro, M. C. Miller, W. J. Allard, W. Gajewski, R. Kurman, R. C. Bast, S. J. Skates, Gynecologic oncology 2009, 112, 40.

[6] M. Montagnana, E. Danese, S. Giudici, M. Franchi, G. C. Guidi, M. Plebani, G. Lippi, Adv Clin Chem 2011, 55, 1; U. Menon, M. Griffin, A. Gentry-Maharaj, Gynecol Oncol 2014, 132, 490; M. A. Karlsen, N. Sandhu, C. Hogdall, I. J. Christensen, L. Nedergaard, L. Lundvall, S. A. Engelholm, A. T. Pedersen, D. Hartwell, M. Lydolph, I. A. Laursen, E. V. Hogdall, Gynecol Oncol 2012, 127, 379; F. Dayyani, S. Uhlig, B. Colson, K. Simon, V. Rolny, D. Morgenstern, M. Schlumbrecht, Int J Gynecol Cancer 2016, 26, 1586.

[7] B.M.Nolen, A. E. Lokshin, Future Oncol 2012, 8, 55.

[8] B. M. Nolen, A. E. Lokshin, Int J Biol Markers 2011, 26, 141.

[9] C. Schmidt, J Natl Cancer Inst 2009, 101, 8.

[10] A. J.Rai, C. A. Gelfand, B. C. Haywood, D. J. Warunek, J. Yi, M. D. Schuchard, R. J. Mehigh, S. L. Cockrill, G. B. Scott, H. Tammen, P. Schulz-Knappe, D. W. Speicher, F. Vitzthum, B. B. Haab, G. Siest, D. W. Chan, Proteomics 2005, 5, 3262.

[11] S. Decramer, A. Gonzalez de Peredo, B. Breuil, H. Mischak, B. Monsarrat, J. L. Bascands, J. P. Schanstra, Mol Cell Proteomics 2008, 7, 1850.

[12] J. Adachi, C. Kumar, Y. Zhang, J. V. Olsen, M. Mann, Genome Biol 2006, 7, R80.

[13] E. Gianazza, I. Miller, L. Palazzolo, C. Parravicini, I. Eberini, J Proteomics 2016, 140, 62.

[14] S.Thomas, L. Hao, W. A. Ricke, L. Li, Proteomics Clin Appl 2016, 10, 358.

This article is protected by copyright. All rights reserved. 
[15] I. Hellstrom, P. J. Heagerty, E. M. Swisher, P. Liu, J. Jaffar, K. Agnew, K. E. Hellstrom, Cancer Lett 2010, 296, 43.

[16] I. Hellstrom, K. E. Hellstrom, Expert Opin Med Diagn 2011, 5, 227.

[17] Z. Xu, C. Wu, F. Xie, G. W. Slysz, N. Tolic, M. E. Monroe, V. A. Petyuk, S. H. Payne, G. M. Fujimoto, R. J. Moore, T. L. Fillmore, A. A. Schepmoes, D. A. Levine, R. R. Townsend, S. R. Davies, S. Li, M. Ellis, E. Boja, R. Rivers, H. Rodriguez, K. D. Rodland, T. Liu, R. D. Smith, J Proteome Res 2015, 14, 422; N. Ahmed, D. Greening, C. Samardzija, R. M. Escalona, M. Chen, J. K. Findlay, G. Kannourakis, Scientific reports 2016, 6, 30061.

[18] C. R. Smith, I. Batruch, J. M. Bauca, H. Kosanam, J. Ridley, M. Q. Bernardini, F. Leung, E. P. Diamandis, V. Kulasingam, Clin Proteomics 2014, 11, 23.

[19] A. Rainczuk, M. Condina, M. Pelzing, S. Dolman, J. Rao, N. Fairweather, T. Jobling, A. N. Stephens, JProteome Res 2013, 12, 4074.

[20] J. R. Wisniewski, A. Zougman, N. Nagaraj, M. Mann, Nature methods 2009, 6, 359.

[21] J. Cox, N. Neuhauser, A. Michalski, R. A. Scheltema, J. V. Olsen, M. Mann, Journal of proteome research 2011, 10, 1794.

[22] J. A Vizcaino, A. Csordas, N. Del-Toro, J. A. Dianes, J. Griss, I. Lavidas, G. Mayer, Y. PerezRiverol, F. Reisinger, T. Ternent, Q. W. Xu, R. Wang, H. Hermjakob, Nucleic acids research 2016, 44,11033 .

[23] B. MacLean, D. M. Tomazela, N. Shulman, M. Chambers, G. L. Finney, B. Frewen, R. Kern, D. L. Tabb, D.C.Liebler, M. J. MacCoss, Bioinformatics 2010, 26, 966.

[24] X. Robin, N. Turck, A. Hainard, N. Tiberti, F. Lisacek, J. C. Sanchez, M. Muller, BMC bioinformatics 2011, 12, 77 .

[25] M. Uhlen, E. Bjorling, C. Agaton, C. A. Szigyarto, B. Amini, E. Andersen, A. C. Andersson, P. Angelidou, A. Asplund, C. Asplund, L. Berglund, K. Bergstrom, H. Brumer, D. Cerjan, M. Ekstrom, A. Elobeid, C. Eriksson, L. Fagerberg, R. Falk, J. Fall, M. Forsberg, M. G. Bjorklund, K. Gumbel, A. Halimi, I. Hallin, C. Hamsten, M. Hansson, M. Hedhammar, G. Hercules, C. Kampf, K. Larsson, M. Lindskog, W. Lodewyckx, J. Lund, J. Lundeberg, K. Magnusson, E. Malm, P. Nilsson, J. Odling, P. Oksvold, I. Olsson, E. Oster, J. Ottosson, L. Paavilainen, A. Persson, R. Rimini, J. Rockberg, M. Runeson, A. Siventsson, A. Skollermo, J. Steen, M. Stenvall, F. Sterky, S. Stromberg, M. Sundberg, H. Tegel, S. Tourle, E. Wahlund, A. Walden, J. Wan, H. Wernerus, J. Westberg, K. Wester, U. Wrethagen, L. L. Xu, S. Hober, F. Ponten, Mol Cell Proteomics 2005, 4, 1920.

[26] S. S. Sundar, H. Zhang, P. Brown, S. Manek, C. Han, K. Kaur, M. F. Charnock, D. Jackson, T. S. Ganesan, Br J Cancer 2006, 94, 1650.

This article is protected by copyright. All rights reserved. 
[27] E. Bignotti, R. A. Tassi, S. Calza, A. Ravaggi, E. Rossi, C. Donzelli, P. Todeschini, C. Romani, E. Bandiera, L. Zanotti, M. Carnazza, F. Quadraro, G. Tognon, E. Sartori, S. Pecorelli, D. M. Roque, A. D. Santin, J Transl Med 2013, 11, 162.

[28] A. Bourmaud, S. Gallien, B. Domon, Proteomics 2016, 16, 2146.

[29] J. D. Worboys, J. Sinclair, Y. Yuan, C. Jorgensen, Nat Methods 2014, 11, 1041.

[30] R. Aebersold, A. L. Burlingame, R. A. Bradshaw, Mol Cell Proteomics 2013, 12, 2381; G. Mermelekas, A. Vlahou, J. Zoidakis, Expert Rev Mol Diagn 2015, 15, 1441.

[31] N. Rauniyar, Int J Mol Sci 2015, 16, 28566.

[32] J. B. Liao, Y. Y. Yip, E. M. Swisher, K. Agnew, K. E. Hellstrom, I. Hellstrom, Gynecol Oncol $2015,137,43$

[33] M. A. Gillette, S. A. Carr, Nat Methods 2013, 10, 28.

[34] B. Domon, S. Gallien, Proteomics Clin Appl 2015, 9, 423; C. Krisp, S. A. Randall, M. J. McKay, M. P. Molloy, Proteomics Clin Appl 2012, 6, 42.

[35] F. Cioppi, L. Simi, P. Luciani, F. Petraglia, T. Susini, L. Cobellis, M. Serio, M. Maggi, A. Peri, Oncol Rep 2004, 11, 427; R. Tanaka, T. Saito, N. Shijubo, M. Takehara, G. Yamada, I. Kawabata, Y. Itoh, R. Kudo, Int) Cancer 2004, 109, 43.

[36] A. B. Mukherjee, Z. Zhang, B. S. Chilton, Endocr Rev 2007, 28, 707.

[37] C. M.Perks, J. M. Holly, J Cell Commun Signal 2015, 9, 159.

[38] H.K. Kong,J. H. Park, BMB Rep 2012, 45, 595.

[39] C. L. Loughner, E. A. Bruford, M. S. McAndrews, E. E. Delp, S. Swamynathan, S. K. Swamynathan, Hum Genomics 2016, 10, 10.

[40] M. Whten, L. Fagerberg, B. M. Hallstrom, C. Lindskog, P. Oksvold, A. Mardinoglu, A. Sivertsson, C. Kampf, E. Sjostedt, A. Asplund, I. Olsson, K. Edlund, E. Lundberg, S. Navani, C. A. Szigyarto, J. Odeberg, D. Djureinovic, J. O. Takanen, S. Hober, T. Alm, P. H. Edqvist, H. Berling, H. Tegel, J. Mulder, J. Rockberg, P. Nilsson, J. M. Schwenk, M. Hamsten, K. von Feilitzen, M. Forsberg, L. Persson, F. Johansson, M. Zwahlen, G. von Heijne, J. Nielsen, F. Ponten, Science 2015, 347, 1260419.

[41] K. Ioannou, P. Samara, E. Livaniou, E. Derhovanessian, O. E. Tsitsilonis, Cancer Immunol Immunother 2012, 61, 599.

[42] I. F. Voutsas, N. Pistamaltzian, M. L. Tsiatas, M. Skopeliti, T. Katsila, I. Mavrothalassiti, S. Spyrou, M.A. Dimopoulos, O. E. Tsitsilonis, A. Bamias, Eur J Cancer 2013, 49, 1706.

This article is protected by copyright. All rights reserved. 
[43] M. J. Engelen, H. E. Kos, P. H. Willemse, J. G. Aalders, E. G. de Vries, M. Schaapveld, R. Otter, A. G. van der Zee, Cancer 2006, 106, 589.

[44] M.Canis, B. Rabischong, C. Houlle, R. Botchorishvili, K. Jardon, A. Safi, A. Wattiez, G. Mage, J. L. Pouly, M.A. Bruhat, Current opinion in obstetrics \& gynecology 2002, 14, 423.

[45] M.E. Carney, J. M. Lancaster, C. Ford, A. Tsodikov, C. L. Wiggins, Gynecol Oncol 2002, 84, 36.

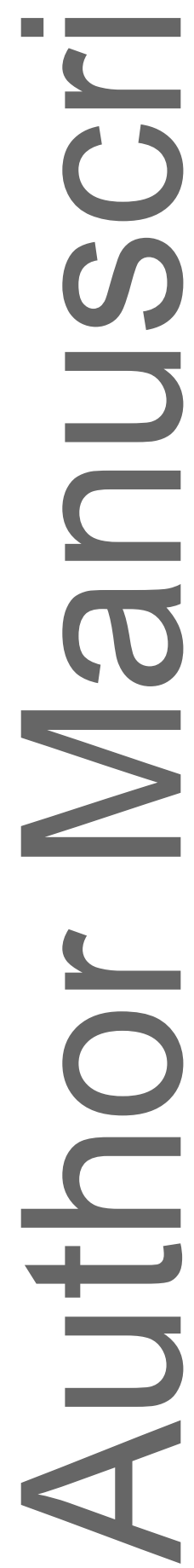

This article is protected by copyright. All rights reserved. 


\section{FIGURE LEGENDS}

Figure 1. Workflow describing LFQ and PRM analysis. Independent sample sets of 10 ovarian cancer and 10 benign urine samples were used for each workflow (total $n=40$ ). Proteins were digested using the FASP method, followed by nano-LC and high-resolution Orbitrap analysis. Label-free quantitation and Parallel Reaction Monitoring analysis were performed using MaxQuant and Skyline software.

Figure 2. Box plot of $\log _{2}$ intensity distributions of samples used in the LFQ discovery workflow. Results from patient samples demonstrated low systematic variation both within and between patient groups as determined by similar median values and quantiles.

Figure 3. Summary of protein and peptide counts after LC-MS/MS analysis. (A) Protein and (B) unique peptide identifications found per sample, and across each group. (C) Venn diagrams showing the distribution of unique proteins and (D) unique peptide identifications between benign and late stage cancer groups. A complete list of proteins corresponding to each group are shown in Supplementary Table 1.

Figure 4. Quantitative analysis of differentially expressed proteins in ovarian cancer. Highlighted proteins were significantly enriched in ovarian cancer patient urine. Protein intensity ratios with a fold change exceeding one standard deviation and a $\log _{10} p$-value $<0.05$ were considered significantly changed. Blue line $=1 \mathrm{SD}$, red line $=2 \mathrm{SD}$. A complete list of proteins corresponding to each group are shown in Supplementary Table 2.

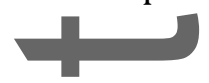

Figure 5. Proteins found in benign and late stage disease validated by PRM. Box plot showing $\log 2$ sum fragment area of identified peptides from seven proteins targeted by PRM. Averages (dotted line) and medians (solid line) were calculated on the sum fragment area for peptides

This article is protected by copyright. All rights reserved. 
from each protein and the number of patients in each group $(n=10)$. Seven proteins found in the initial LFQ were significantly increased (Wilcoxon rank sum test, $\mathrm{p}<0.05$ ) in late stage disease $(n=10)$ compared to benign samples $(n=10)$. The sum fragment area of each biological replicate for each peptide targeted by PRM is shown in Supplementary Fig.2. Significance of the PRM data was determined using a Wilcoxon rank sum test based on the summed protein area under the curve $(\mathrm{AUC}) .^{*} \mathrm{p}<0.05,{ }^{* *} \mathrm{p}<0.01,{ }^{* * *} \mathrm{p}<0.001$

Figure 6. ROC analysis was performed for the ovarian cancer patients against benign patients using the $\log 2$ summed intensity values for peptides analyzed using PRM for each selected protein.

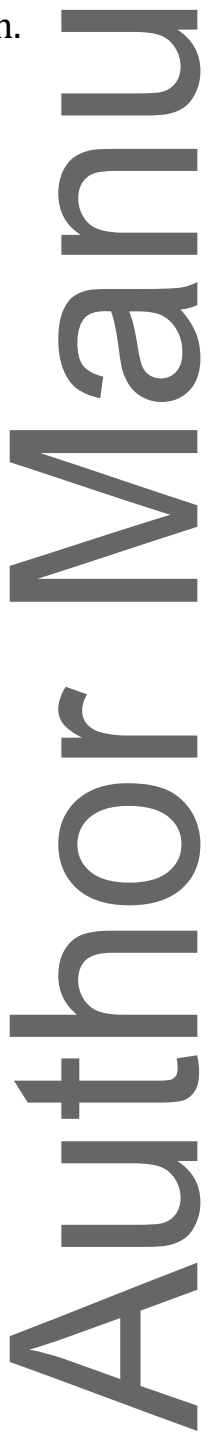

This article is protected by copyright. All rights reserved. 
Table 1. Summary of patient samples

\begin{tabular}{|c|c|c|}
\hline Patient groups & $\begin{array}{c}\text { Serous Cancer Late } \\
\text { "late" }\end{array}$ & $\begin{array}{c}\text { Benign - ovarian related } \\
\text { "benign" }\end{array}$ \\
\hline Exp. Cohort $1 n=$ & 10 & 10 \\
\hline $\begin{array}{l}\text { Exp. Cohort } 2 \text { (PRM validation) } \\
n=\end{array}$ & 10 & 10 \\
\hline Stage & 3 & $\mathrm{n} / \mathrm{a}$ \\
\hline median age at diagnosis (Q3-Q1) & $73(17)$ & $69(12)$ \\
\hline Median (Q3-Q1) CA125 (U/ml) & $575(1315)$ & $15(24)$ \\
\hline Pathology & Serous adenocarcinoma & $\begin{array}{c}\text { Ovarian fibroma, simple } \\
\text { cysts, serous } \\
\text { cystadenoma }\end{array}$ \\
\hline
\end{tabular}

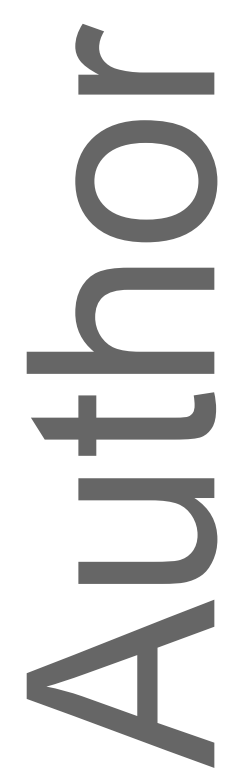

This article is protected by copyright. All rights reserved. 
Table 2. Proteins increased in late stage ovarian cancer samples after LFQ and PRM analysis using an independent sample set. 1 Human Protein Atlas available from www.proteinatlas.org $[25,40],{ }^{2}$ All links to Human Protein Atlas data are shown in Supplementary Table 2 .

\begin{tabular}{|c|c|c|c|c|}
\hline $\begin{array}{l}\text { Gene } \\
\text { Name }\end{array}$ & Protein Name \& accession & $\begin{array}{c}\text { Human } \\
\text { Protein } \\
\text { Atlas: } \\
\text { Cancer } \\
\text { Tissue } \\
\text { Expressio } \\
\mathbf{n}^{1,2} \\
\text { (See } \\
\text { Supp } \\
\text { Table 2 } \\
\text { for links) }\end{array}$ & $\begin{array}{c}\text { Human } \\
\text { Protein } \\
\text { Atlas: } \\
\text { Normal } \\
\text { expression } \\
\text { ovary/fallo } \\
\text { pian tube }\end{array}$ & $\begin{array}{l}\text { Peptides used for PRM } \\
\text { quantitation }\end{array}$ \\
\hline IGFBP3 & $\begin{array}{l}\text { Insulin-like growth factor-binding protein } 3 \\
\text { A6XND1 }\end{array}$ & $\begin{array}{l}91 \% \\
\text { medium- } \\
\text { high } \\
\text { intensity }\end{array}$ & $\begin{array}{l}\text { Medium - } \\
\text { fallopian } \\
\text { tube }\end{array}$ & $\begin{array}{l}\text { ALAQCAPPPAVCAELVR } \\
\text { CQPSPDEARPLQALLDGR } \\
\text { EPGCGCCLTCALSEGQPCGIYTER }\end{array}$ \\
\hline LYPD1 & Ly6/PLAUR domain-containing protein 1 Q8N2G4| & $\begin{array}{l}100 \% \\
\text { medium } \\
\text { intensity }\end{array}$ & $\begin{array}{l}\text { No data at } \\
\text { protein level }\end{array}$ & $\begin{array}{l}\text { EVMEQSAGIMYR } \\
\text { SCASSAACLIASAGYQSFCSPGK }\end{array}$ \\
\hline LYVE1 & $\begin{array}{l}\text { Lymphatie vessel endothelial hyaluronic acid receptor } 1 \\
\text { Q9Y5Y7 }\end{array}$ & $\begin{array}{l}\text { Not } \\
\text { detected } \\
\text { at protein } \\
\text { level }- \text { in } \\
\text { contrast to } \\
\text { [26] }\end{array}$ & $\begin{array}{l}\text { No data at } \\
\text { protein level }\end{array}$ & $\begin{array}{l}\text { ANQQLNFTEAK } \\
\text { DQVETALK } \\
\text { IMGITLVSK } \\
\text { LLGLSLAGK } \\
\text { NGVGVLIWK }\end{array}$ \\
\hline MSLN & $\begin{array}{l}\text { Mesothelin; Megakaryocyte-potentiating factor; } \\
\text { Mesothelin, cleaved form. } \\
\text { Q13421-2 }\end{array}$ & $\begin{array}{l}83 \% \\
\text { medium- } \\
\text { high } \\
\text { intensity }\end{array}$ & $\begin{array}{l}\text { High - } \\
\text { fallopian } \\
\text { tube }\end{array}$ & $\begin{array}{l}\text { EIDESLIFYK } \\
\text { GHEMSPQVATLIDR } \\
\text { IQSFLGGAPTEDLK } \\
\text { LLGPHVEGLK } \\
\text { QLDVLYPK } \\
\text { TDAVLPLTVAEVQK } \\
\text { VNAIPFTYEQLDVLK }\end{array}$ \\
\hline PTMA & $\begin{array}{l}\text { Prothymosin alpha } \\
\text { B8zZQ6 }\end{array}$ & $\begin{array}{l}100 \% \\
\text { medium } \\
\text { intensity }\end{array}$ & $\begin{array}{l}\text { High - } \\
\text { fallopian } \\
\text { tube }\end{array}$ & EVVEEAENGR \\
\hline SCGB1A1 & $\begin{array}{l}\text { Uteroglobin } \\
\text { P11684 }\end{array}$ & $\begin{array}{l}\text { Not } \\
\text { detected } \\
\text { at protein } \\
\text { level - in } \\
\text { contrast to }\end{array}$ & $\begin{array}{l}\text { No data at } \\
\text { protein level } \\
- \text { in contrast } \\
\text { to }{ }^{[27]}\end{array}$ & $\begin{array}{l}\text { KLVDTLPQKPR } \\
\text { LVDTLPQKPR } \\
\text { VIETLLMDTPSSYEAAMELFSPDQD } \\
\text { MR }\end{array}$ \\
\hline
\end{tabular}

This article is protected by copyright. All rights reserved. 


\begin{tabular}{|c|c|c|c|c|}
\hline & & $\mid 27]$ & & \\
\hline WFDC2 & $\begin{array}{l}\text { WAP four-disulfide core domain protein } 2 \text { (HE4) } \\
\text { Q14508 }\end{array}$ & $\begin{array}{l}92 \% \\
\text { medium- } \\
\text { high } \\
\text { intensity }\end{array}$ & $\begin{array}{l}\text { Medium - } \\
\text { fallopian } \\
\text { tube }\end{array}$ & $\begin{array}{l}\text { CCSAGCATFCSLPNDK } \\
\text { CCSAGCATFCSLPNDKEGSCPQVNI } \\
\text { NFPQLGLCR } \\
\text { DQCQVDSQCPGQMK } \\
\text { EGSCPQVNINFPQLGLCR } \\
\text { VSCVTPNFK }\end{array}$ \\
\hline
\end{tabular}
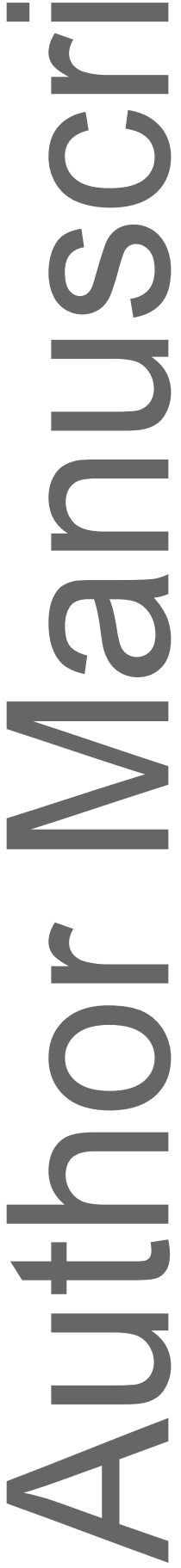

This article is protected by copyright. All rights reserved. 
Table 3. Comparison of significantly differentially enriched protein data between the LFQ patient cohort and PRM patient cohort. ${ }^{*} \mathrm{CA} 125$ was measured in the clinic as part of routine Ovarian Cancer diagnosis and treatment (not mass spectrometry analysis). CA125 measurements were taken from the identical patient cohort as those used for the PRM analysis.

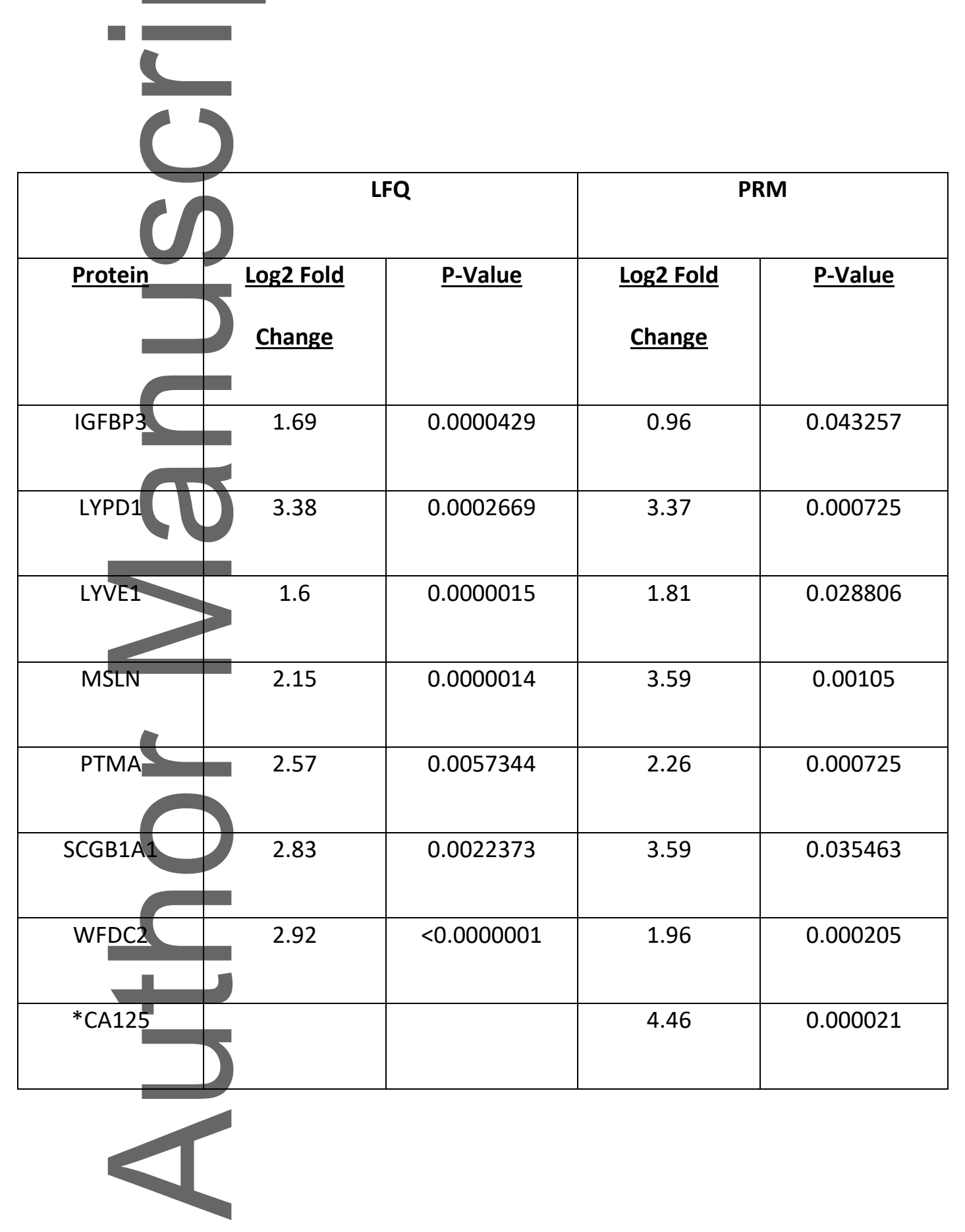

This article is protected by copyright. All rights reserved. 

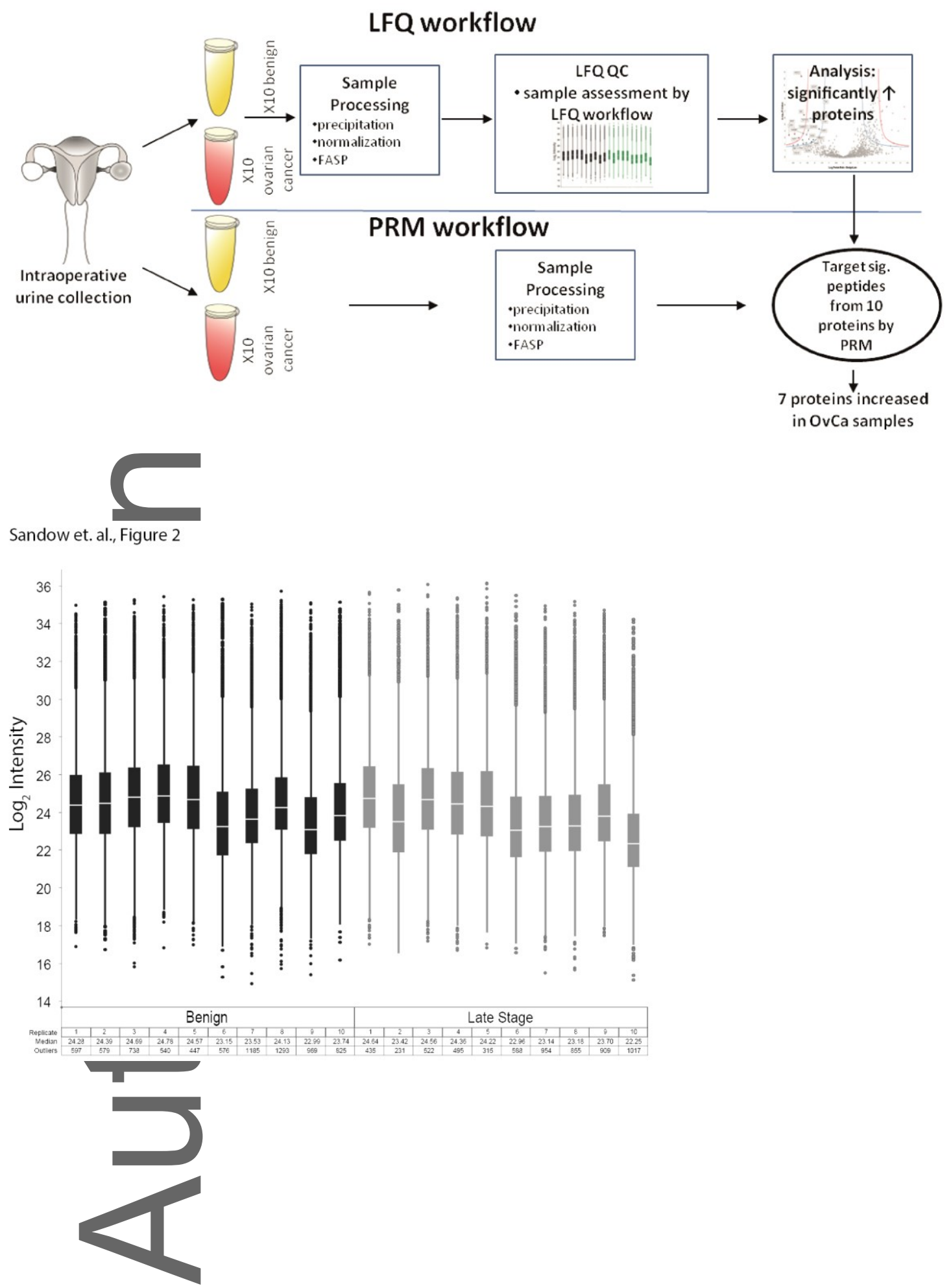

This article is protected by copyright. All rights reserved. 
Sandow et. al., Figure 3
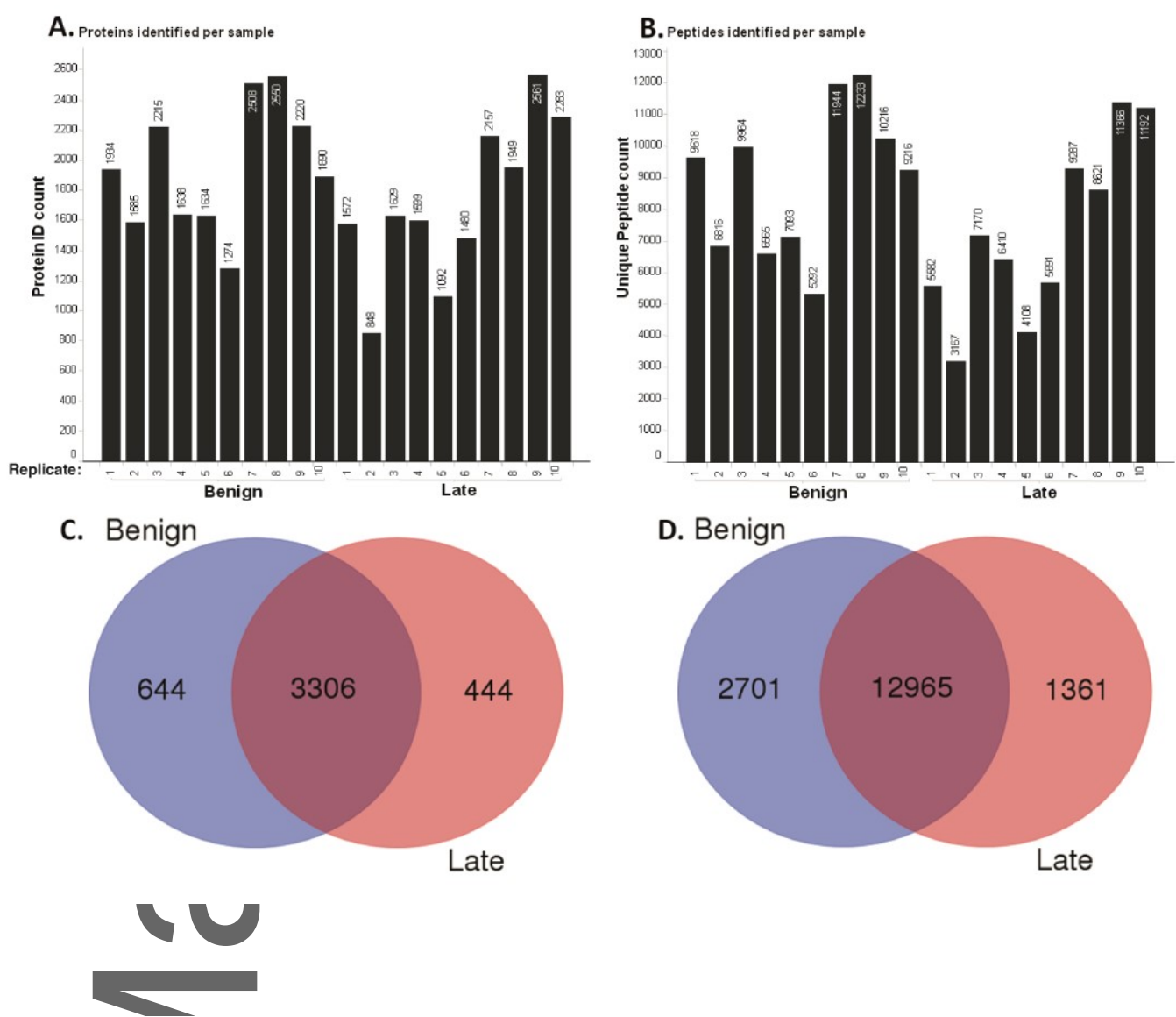

Sandow et. al., Figure 4

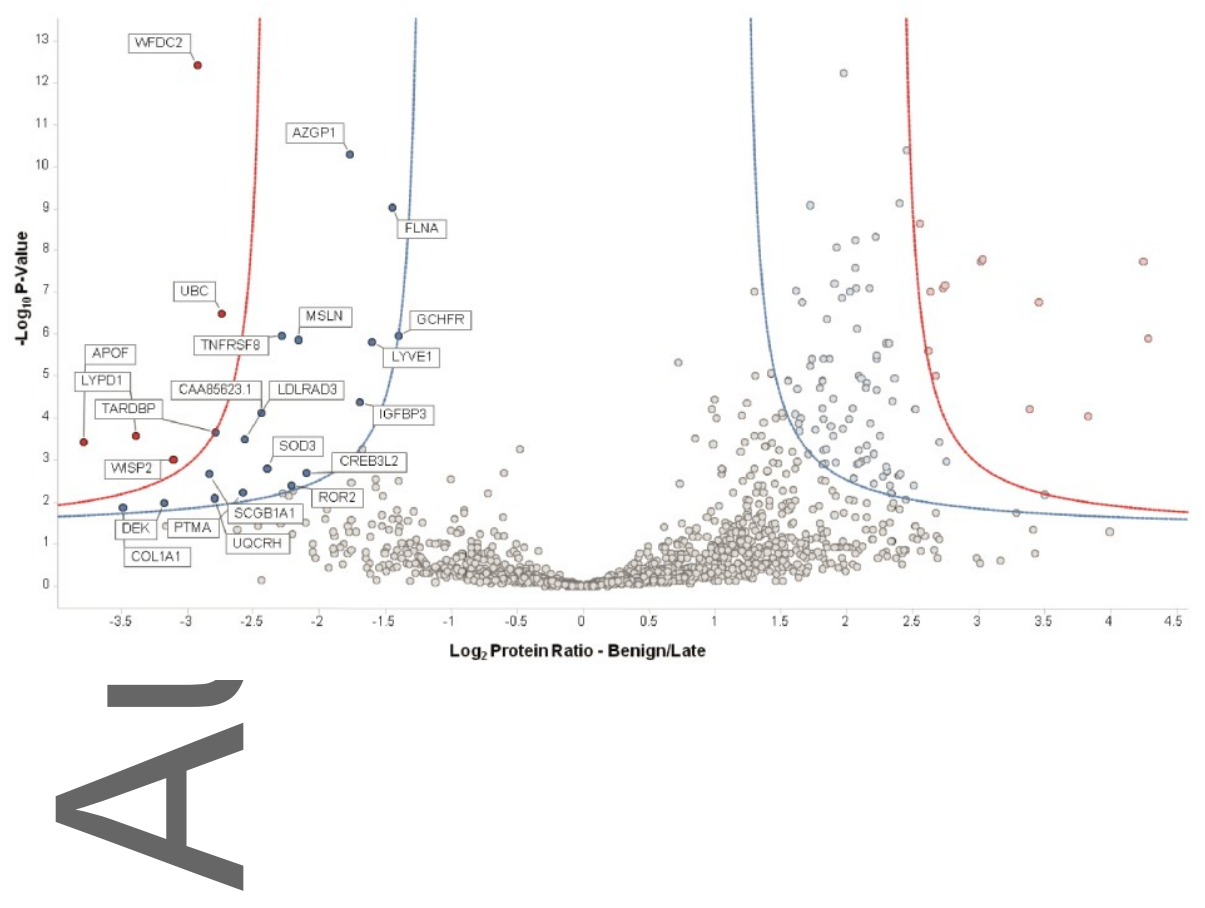

This article is protected by copyright. All rights reserved. 
Sandow et. al., Figure 5

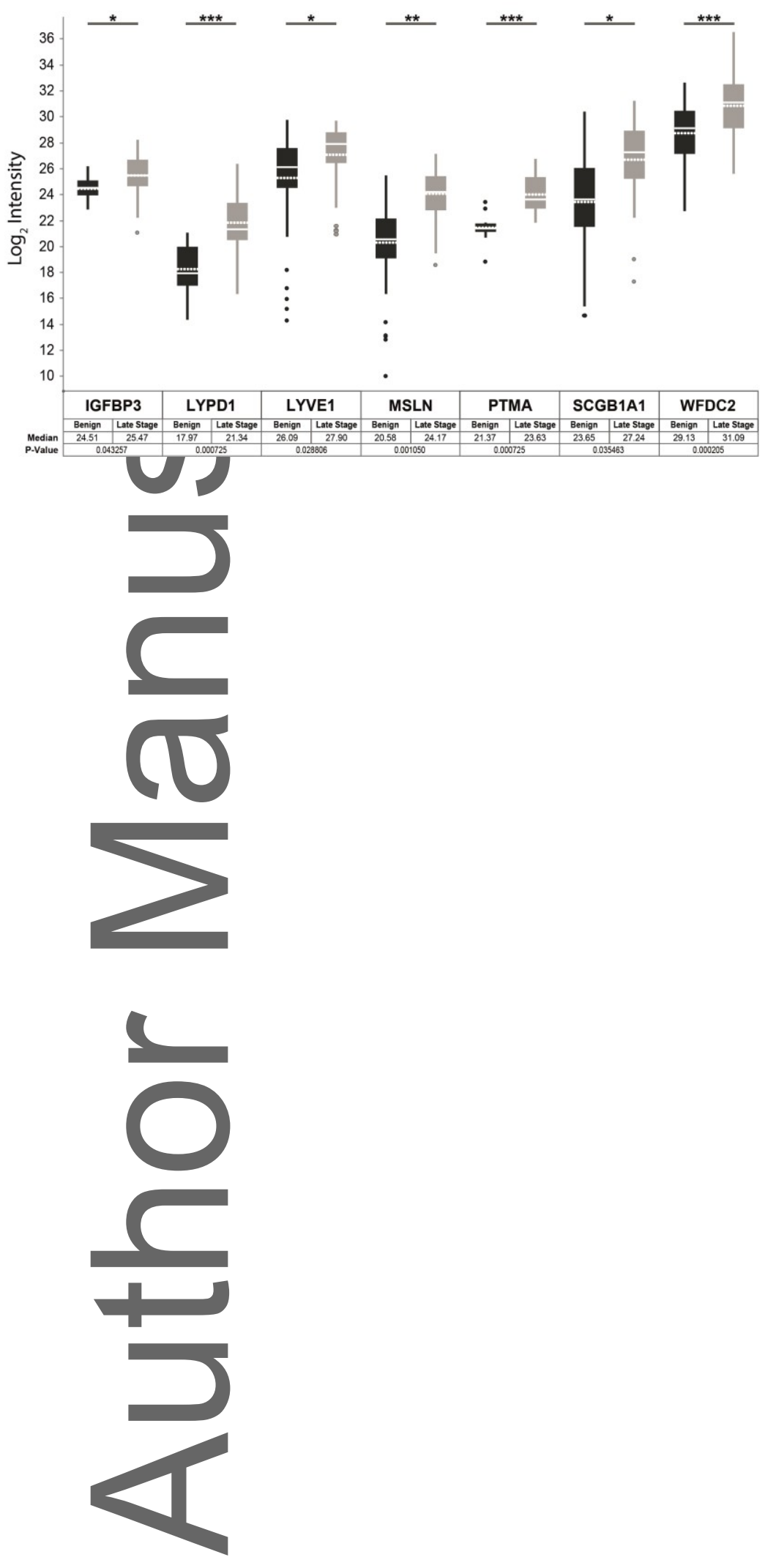

This article is protected by copyright. All rights reserved. 
Sandow et. al., Figure 6
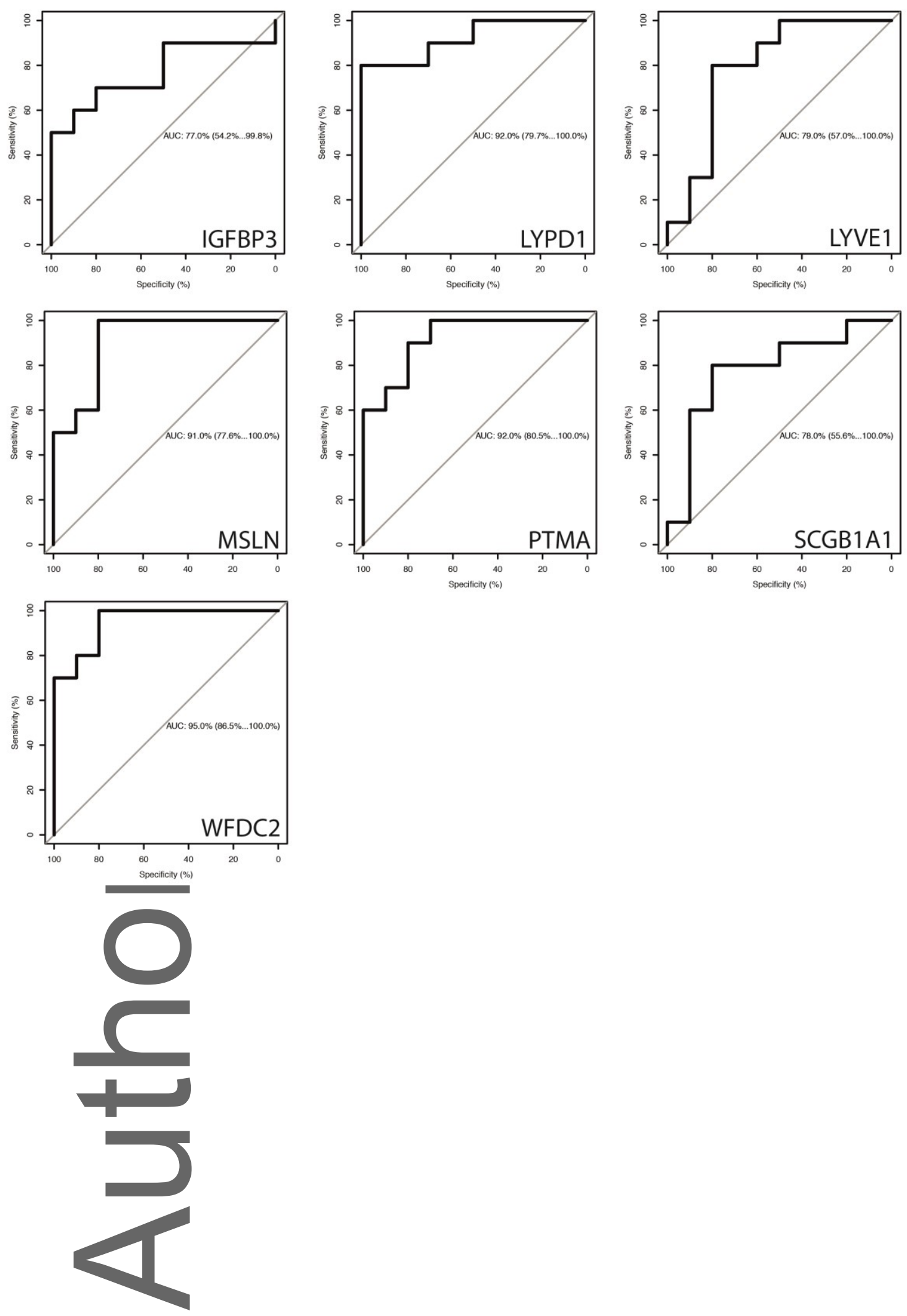

This article is protected by copyright. All rights reserved. 


\section{University Library}

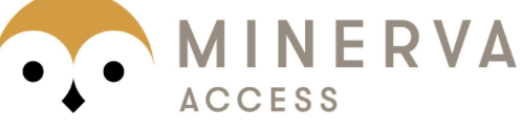

A gateway to Melbourne's research publications

Minerva Access is the Institutional Repository of The University of Melbourne

Author/s:

Sandow, JJ;Rainczuk, A;Infusini, G;Makanji, M;Bilandzic, M;Wilson, AL;Fairweather, N;Stanton, PG;Garama, D;Gough, D;Jobling, TW;Webb, Al;Stephens, AN

Title:

Discovery and Validation of Novel Protein Biomarkers in Ovarian Cancer Patient Urine

Date:

2018-05-01

Citation:

Sandow, J. J., Rainczuk, A., Infusini, G., Makanji, M., Bilandzic, M., Wilson, A. L., Fairweather, N., Stanton, P. G., Garama, D., Gough, D., Jobling, T. W., Webb, A. I. \& Stephens, A. N. (2018). Discovery and Validation of Novel Protein Biomarkers in Ovarian Cancer Patient Urine. PROTEOMICS CLINICAL APPLICATIONS, 12 (3), https:// doi.org/10.1002/prca.201700135.

Persistent Link:

http://hdl.handle.net/11343/283581 